\title{
Abordagem etimológica e histórica do leigo no catolicismo
}

\author{
Etymological and historical approach of laymen in Catholicism
}

\section{Sávio Carlos Desan Scopinho}

Doutor em Teologia Dogmática pela Pontifícia Universidade Gregoriana de Roma, Mestre em Filosofia pela Pontifícia Universidade Católica de Campinas, professor e diretor acadêmico das Faculdades Integradas Claretianas de Rio Claro, SP - Brasil, e-mail: savio@claretianas.br

\section{Resumo}

Este artigo pretende desenvolver uma reflexão sobre a abordagem etimológica e histórica do laicato na Igreja Católica. Depois de apresentar o sentido etimológico da palavra leigo no início do Cristianismo, o artigo propõe uma compreensão histórica do conceito, tendo presente os quatro períodos da história da Igreja Católica - primitivo, medieval, moderno e contemporâneo. A compreensão do laicato no contexto eclesial contemporâneo depende de uma clara compreensão desse itinerário etimológico e histórico. Em seguida, a proposta é apresentar a teologia e a eclesiologia subjacentes a cada período da história, enfocando a ideia de uma teologia apologética e uma eclesiologia que entende que fora da Igreja não há salvação. Tal contexto histórico e respectiva abordagem teológica, particularmente eclesiológica, contribuirão para entender os desafios e impasses da questão do laicato no interior da Igreja Católica e na sua relação com a sociedade contemporânea.

Palavras-chave: Laicato. Catolicismo. Teologia. Eclesiologia e história. 


\section{Abstract}

This article aims to develop a reflection about the etymological and historical approach of laymen in the Catholic Church. After presenting the etymological meaning of the word "layman" in the beginning of Christianism, this article will propose a historical comprehension of the concept through the four periods of the Catholic Church (primitive, medieval, modern and contemporary). The comprehension of laymen on the current contemporary ecclesial context depends on a clear comprehension of this etymological and historical itinerary. Following this, another aim is to present the subjacent theology and ecclesiology in each period of history, focusing on the idea of an apologetic theology and on an ecclesiology, which is able to understand that there is no salvation out of church. Such historical context and theological approach, mainly the ecclesiologic, will contribute to the understanding of the challenges and impasses of the laymen issue inside the Catholic Church and in its relationship with the contemporary society.

Keywords: Laity. Catholicism. Theology. Ecclesiology and history.

\section{Introdução}

A questão do laicato na Igreja Católica tem sido objeto de preocupação no meio teológico, nos documentos do magistério eclesiástico, assim como nos contextos pastoral e social. Diante dessa constatação, percebe-se a necessidade de uma abordagem etimológica e histórica da palavra leigo na perspectiva do catolicismo. Assim, entende-se que é importante situar a temática do laicato na Igreja e na sociedade, tendo como referência uma interpretação histórica e doutrinal. É o que se pretende desenvolver no presente artigo, partindo-se do fato de que não é possível entender um tema atual sem conhecer seu significado etimológico e sua evolução histórica.

Parte-se do princípio de que é importante conhecer a origem e a história do termo leigo para, assim, compreender o seu uso no catolicismo e elaborar uma reflexão que evite repetir temas já desenvolvidos pela própria teologia. Também é importante salientar outra preocupação: todo texto é fruto de um contexto e é sempre interpretado por quem o lê - isso acontece 
também na teologia, que apresenta enfoques diferentes de um mesmo fato, a partir do lugar social e epistêmico de onde se elabora a reflexão. Por isso que uma reflexão sobre a questão do laicato no contexto atual exige uma retomada da forma como esse mesmo laicato foi compreendido na história do catolicismo e na doutrina do magistério eclesiástico.

Assim, com esses referenciais de análise, será apresentada uma leitura da origem etimológica do termo leigo, assim como sua evolução histórica até o momento que antecede à realização do Concílio Vaticano II (19621965). Caberá ao leitor fazer a sua hermenêutica, percebendo as implicações que o sentido etimológico e histórico trouxe para a compreensão do termo leigo no atual contexto da vida eclesial, eclesiástica e social contemporânea.

\section{O significado semântico}

É difícil contextualizar o significado da palavra leigo, tendo como referência o mundo judaico-cristão. Uma primeira constatação é que, na sua origem bíblica, a palavra leigo significava povo, em oposição às nações pagãs. Mas essa origem não é suficiente para entender o uso da palavra na história posterior do cristianismo. Em outra interpretação, leigo referia-se a povo, não em confronto com outra nação, considerada pagã, mas como uma categoria oposta e inferior a outra categoria, dentro de uma mesma sociedade. Segundo Schillebeeckx (1965, p. 982), “o termo 'laos', de que 'laikos' ou leigo se deriva, refere-se na Escritura ao povo de Deus, mas, sob a influência grega, esse termo foi empregado precisamente em oposição aos líderes deste povo". O termo identificava-se, assim, com a população distinta daqueles que administravam ou dirigiam uma determinada estrutura social.

Diante da segunda interpretação apresentada, o termo leigo (do

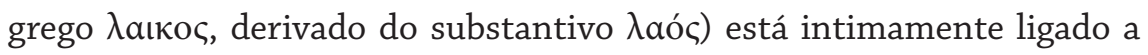
duas situações, que se complementam entre si. Uma situação é a distinção presente no interior de um mesmo grupo social, em que laós é entendido como povo inferior, que se distingue dos seus chefes. Portanto, é diferente do sentido bíblico mais primitivo, que considerava laós como todo um povo consagrado a Deus, distinto dos povos pagãos. A outra situação diz que a palavra leigo está inserida num contexto cultual, conotação presente 
no cristianismo, a partir da noção veterotestamentária de sacerdote, entendido como alguém ligado diretamente ao culto e ao sagrado. Trata-se, nesse caso, de um coletivo sacerdotal, estabelecido e separado do resto do povo. Essa linguagem cultual já se encontrava em vários textos não cristãos, como nos papiros egípcios do terceiro século antes da era cristã.

Assim, os leigos foram entendidos como aqueles que assistem às cerimônias do culto e não se relacionam diretamente com o sagrado. Tal interpretação fez com que surgisse uma oposição entre sagrado e profano, que se traduziu na oposição clérigo e leigo. É importante lembrar também que, num primeiro momento, o conceito dizia respeito às coisas e aos objetos utilizados no ambiente de culto. Não se referia diretamente às pessoas, como foi empregado posteriormente pelo catolicismo. "Nos primeiros escritos da Igreja, contudo, como em S. Clemente de Roma, a palavra 'laikos' já era aplicada a pessoas, e assim surge a distinção entre as duas palavras significativas: clericus e laicus" (SCHILLEBEECKX, 1965, p. 997).

Essa origem semântica assumida na história do catolicismo apresentou várias implicações para a reflexão teológica, já nos primeiros séculos do cristianismo. O tema será retomado a partir dos períodos patrístico, medieval e moderno. Eles são momentos necessários e importantes para entender os problemas e os desafios teológicos e eclesiológicos do catolicismo na sociedade contemporânea.

\section{0 período patrístico}

No período patrístico, o laicato era compreendido e interpretado levando-se em consideração determinados problemas que aparecerão no catolicismo posterior.

Quando surge propriamente o termo leigo na história do cristianismo? Inicialmente deve-se partir do fato de que o referido termo quase não se encontra na Igreja dos primeiros três séculos da era cristã. São poucos os textos que apresentam essa terminologia. As primeiras vezes que se encontra a palavra $\lambda$ aıkৎ são nos seguintes autores: uma única passagem em Clemente de Roma, três em Clemente de Alexandria e uma em Orígenes. É significativa a apresentação de Clemente de Roma, em que a 
palavra foi usada pela primeira vez. Escrevendo aos cristãos de Corinto, entre os anos 96-98 d.C., Clemente faz uma distinção no interior da comunidade, retomando o esquema veterotestamentário de "sumo sacerdote, sacerdote e levita". Foi a partir dessa distinção que Clemente apresentou o leigo numa condição diferente de todos eles, sendo entendido como o cristão que não faz parte dessa tríade; assim, o leigo não participaria, portanto, diretamente do contexto sagrado. Essa compreensão foi utilizada, com diferentes conotações, no desenvolvimento do catolicismo posterior, sustentando a interpretação dicotômica entre clero e leigo, que prevaleceu até o Concílio Vaticano II (1962-1965) e que em algumas situações ainda não foram devidamente superadas.

Para Clemente de Roma, os leigos são todos os cristãos que, na relação com o culto, se opõem aos que se ocupam do sagrado, atitude exercida pelas três categorias de pessoas mencionadas. $\mathrm{O}$ aspecto relevante na interpretação de Clemente é que ele usa o termo leigo num contexto de culto e atribui tal categoria especificamente às pessoas, noção que será preponderante no desenvolvimento do catolicismo.

Outro autor que estabelece a distinção é Clemente de Alexandria. Este mantém ainda uma tríplice relação - "padres, levitas e leigos" -, dando uma conotação mais propriamente católica na forma como se desenvolverá no catolicismo posterior. Clemente refere-se ainda à tríade "padres, diáconos e leigos", também num ambiente de culto.

Quem também utiliza o termo leigo na sua reflexão teológica é Orígenes; ele apresenta uma oposição entre leigos e a trilogia "clero, padre e diácono". O leigo, para ele, é uma condição de vida, que diz respeito ao cristão batizado, considerado pecador e necessitado de receber o perdão dos seus pecados, pecados que só podem ser concedidos pelo sumo pontífice. Assim, nota-se que a proposta de Orígenes não é diferente das propostas de Clemente de Roma e de Clemente de Alexandria. Existem vários elementos comuns entre eles.

A partir desse primeiro referencial, o termo se tornou tradicional na história do catolicismo. Na Igreja Católica latina foi sempre empregado, confirmando a conotação dicotômica apresentada. Autores como Tertuliano - quando o termo já estava fixado na própria teologia -, Jerônimo - que utilizava a palavra leigo na tradução da Vulgata - e Cipriano 
sustentaram a compreensão do uso que, no desenvolvimento da história do catolicismo, foi adquirindo expressividade e sustentado no contexto teológico, eclesiológico e social.

Assim, do período patrístico chega-se ao período medieval, momento em que se perceberá uma aplicação direta da concepção e atuação do leigo no interior do cristianismo, de base católica, com características marcadamente hierarcológicas.

\section{0 período medieval}

Para entender as principais ideias sobre o leigo no período medieval, é preciso ter presente como ocorreu o assim denominado catolicismo da cristandade. É possível enumerar, pelo menos, três principais elementos que devem ser considerados nesse período: primeiro, o processo de burocratização e institucionalização da estrutura eclesial; segundo, a entrada do modelo jurídico romano para organizar a doutrina e a vida interna da Igreja; e, terceiro, o desenvolvimento do modelo de vida monástica. A partir desses elementos, a Igreja se identificou com as estruturas sociais vigentes, assimilando os valores das instituições humanas.

O leigo, por sua vez, se tornou uma figura sem expressividade, tanto do ponto de vista eclesial como social. Ele era visto somente como um cristão que exercia as tarefas de ordem temporal, ligadas ao trabalho manual, não podendo participar das atividades relacionadas ao trabalho intelectual. A atuação do leigo se limitava apenas ao mundo material e carnal, que diz respeito às realidades transitórias. Assim, a estrutura eclesiástica, de forte tendência dicotômica, se fortalecia, reconhecendo somente os direitos da autoridade hierarquicamente constituída. A Igreja era entendida a partir da ideia de corpo, apresentando-se como uma unidade diversificada e hierarquizada, sempre sustentando e oficializando a concepção das três ordens, que são a monástica, a clerical e a leiga. A estrutura vigente era piramidal: ampla na base, onde se encontravam os homens carnais e os casados (leigos), e aguda em cima, onde era proposto o árduo caminho da vida religiosa e clerical. Esse modelo foi proposto por Gilberto di Lemerik (+1140) (SEMERARO, 1994, p. 25). 
Havia ainda outra visão, complementar a esta apresentada, que entendia a Igreja como um corpo, com dois lados distintos. Um era o leigo, que devia se preocupar com as tarefas seculares - e o outro era o clero, que tinha como competência cuidar das questões eclesiásticas. Esse segundo modelo foi apresentado por Umberto di Silva Candida (+1061), na sua obra Adversus simoniacos III, 9 (SEMERARO, 1994, p. 25). Existia, assim, uma nítida distinção dos dois planos da ação humana, definidos dicotomicamente como o espiritual e o material, o segundo sempre colocado em situação de inferioridade em relação ao primeiro. As distinções podem ser encontradas em vários textos, inclusive nos documentos pontifícios da época.

Portanto, os dois planos - material e espiritual - distinguem duas categorias de pessoas - o clero e o leigo -, hierarquicamente constituídas. Essa interpretação estava inserida numa realidade histórica complexa e contraditória, com sérias implicações para a evolução do catolicismo posterior. Por outro lado, contraditoriamente, da mesma maneira que a Igreja foi se estruturando hierarquicamente no contexto medieval, havia muitas experiências que valorizavam o aspecto carismático e escatológico, questionando, assim, a estrutura dicotômica vigente.

No ordo laicorum se distinguem diversas categorias, correspondentes às várias funções sociais, abrindo espaço para uma ética de profissão, que se exprime na Specula e nos sermões de várias "ordens". Um exemplo é o De institutione laicali de Giona de Orleans, que escreveu por volta de 830 d.C., constituindo um verdadeiro código de espiritualidade laical. Dos séculos XII ao XV são numerosos os escritos vulgares destinados aos leigos. Também os movimentos que surgiram a partir do século XII apresentavam uma forte orientação para a vida de pobreza e para a radicalidade evangélica; eles se tornaram expressivos no contexto medieval (SEMERARO, 1994, p. 26). Outros exemplos eram as "Confraternitas", que surgiram entre a Idade Média e a Modernidade (ANGELOZZI, 1978). Mas, considerando que no presente estudo a ênfase é para o aspecto institucional e estrutural da Igreja Católica, e que esse enfoque prevaleceu na história do catolicismo, contribuindo para entender a situação do século XX e as mudanças propostas pelo Concílio Vaticano II, não será priorizada a reflexão das experiências relatadas, embora elas tenham significativa importância para entender as contradições inerentes à própria história do catolicismo. 
Nessa perspectiva dialética, a partir de uma longa evolução histórica, a Igreja Católica se deparou com o fenômeno da modernidade. De início, o magistério eclesiástico se posicionou contrariamente aos avanços do mundo moderno, criando oposição e dificuldades. Mas, contraditoriamente, foi a partir desse período que começaram a ocorrer várias inovações na teologia e na eclesiologia, contribuindo para a elaboração de uma "teologia do laicato", cuja base e sustentação serão percebidas mais explicitamente durante a realização do Concílio Vaticano II.

\section{0 período moderno}

Como se apresentou a questão do laicato no período moderno, considerando o posicionamento teológico, pastoral e social da Igreja Católica a respeito? O ponto de partida para a resposta à questão foi a Reforma Protestante. A razão para a escolha desse acontecimento é pelo fato de que Martinho Lutero apresentou uma doutrina sobre o sacerdócio comum dos fiéis, que questionava a doutrina do sacerdócio hierárquico da Igreja Católica. Dizia ele que, pelo batismo, todos os cristãos participam do sacerdócio de Cristo e, portanto, todos são chamados a exercer os seus múnus sacerdotal, régio e profético. Tal posicionamento gerou uma forte oposição da Igreja Católica, que se manifestou e se posicionou por meio do Concílio de Trento (1545-1563). Com a preocupação em responder à "doutrina do sacerdócio comum", proposta por Lutero, o Concílio sustentou e ratificou a doutrina tradicional sobre a autoridade na Igreja. E, nesse sentido, o leigo continuaria subordinado à hierarquia, não podendo exercer nenhuma atividade no contexto eclesial. Sua função seria de obedecer à autoridade eclesiástica e simplesmente receber os sacramentos instituídos pela Igreja.

Nesse contexto, a modernidade se desenvolvia, apresentando e fortalecendo seus valores e princípios. Esses se estruturaram e se sustentaram a partir dos grandes acontecimentos que se realizaram depois do Renascimento e da Reforma Protestante. São eles: o Iluminismo, a Revolução Francesa e a Revolução Industrial.

Num primeiro momento, a Igreja assumiu uma postura de combate a esses acontecimentos, já expressos no Concílio de Trento. Ela os 
considerou como "erros da modernidade" (PIO IX, Syllabus, p. 168-176), caracterizando-os como anátemas que, portanto, deveriam ser combatidos. Mas como combatê-los? A hierarquia eclesiástica católica convocou o laicato, entendido como força auxiliadora e suporte para o trabalho da própria hierarquia. Surgia, assim, a Ação Católica, com a proposta de inserir o leigo nos ambientes em que a hierarquia não tinha possibilidade de atuar. Essa inserção do laicato nas atividades apostólicas de combate às ideias da Modernidade acabou provocando, paradoxalmente, um diálogo da Igreja com o próprio mundo secular. A Instituição Católica se tornou receptiva a determinados valores da sociedade moderna, tais como a liberdade e a subjetividade, entre outros.

Assim, a Igreja, que se confrontava com o mundo moderno, dialeticamente assumiu alguns dos seus elementos. Foi todo um período de profundas transformações, que contribuíram para um processo de mudanças, que culminou com o Concílio Vaticano II, grande marco de mudança no interior da Igreja e na sua relação com a sociedade de seu tempo.

\section{A eclesiologia e a teologia subjacentes}

Toda reflexão é resultado de uma prática. Esta, por sua vez, necessita de uma reflexão, que se sustente por meio de um embasamento teórico para não se tornar somente repetição de fatos passados. Assim, é importante conhecer os elementos teóricos que sustentaram o Catolicismo, principalmente nos períodos medieval e moderno, para ajudar na compreensão do período contemporâneo (ANTÓN, 1986a, b). Dois elementos são relevantes e devem ser mencionados: a ideia de Igreja apresentada como sociedade perfeita e a concepção apologética da teologia.

\section{A igreja como societas perfecta}

A Igreja é uma instituição divina, proposta e fundada por Jesus Cristo, e deve ser entendida como sacramento universal de salvação (LG 1). A partir dessa origem, ela deve, pela mediação do próprio Jesus Cristo 
e através da ação do Espírito Santo, ser sinal do amor de Deus no mundo. Ela se torna sacramentalmente visível na comunidade de fé, chamada a viver em comunhão. Na comunidade, por sua vez, o amor é exercido por meio da dimensão missionária, enquanto compromisso com o mundo. Tais dimensões - trinitária, comunitária e missionária - de toda a Igreja foram enfatizadas pelo Concílio Vaticano II, principalmente na Constituição Dogmática Lumen gentium e no Decreto Ad gentes. Mas, antes do Concílio, não era essa a imagem que a Igreja tinha de si mesma.

No debate eclesiológico medieval e moderno, prevaleceu o modelo de Igreja entendido como sociedade perfeita (ANTÓN, 1986b, II, p. 321-405). Essa concepção foi elaborada a partir de um processo histórico, cujas raízes estão no século quarto da era cristã, com a institucionalização dos carismas no interior da Igreja. Juntamente com esse modelo, desenvolveu-se outra expressão eclesial que entendia a Igreja como única possibilidade de salvação - "extra ecclesiam nulla salus" (DUPUIS, 1991, p. 129-130). Tal concepção foi assumida pelo Concílio de Trento (15451563), que identificava a Igreja com os valores da sociedade, compreendida num plano sobrenatural. Com o papa Pio X é visível essa concepção hierarquizada, a partir da contraposição entre pastores e fiéis, pela relação ecclesia docens e ecclesia discens. Tal concepção está bem expressa na Carta Encíclica de Pio XII, denominada Vehementer Nos, de 11 de fevereiro de 1906 (ANTÓN, 1986b, II, p. 500). Já o papa Gregório XVI (1831-1846) apresentava a Igreja como sociedade de desiguais. Depois, no Concílio Vaticano I (1869-1870), prevaleceu a doutrina da autoridade pontifícia, assim como o fortalecimento da definição institucional da Igreja.

Portanto, foram interpretações eclesiológicas que dificultaram o diálogo com o mundo moderno. A Igreja se considerava estruturalmente perfeita, não questionando seu conteúdo doutrinário diante dos desafios apresentados pela sociedade e julgando-se no direito de expulsar ou condenar aqueles que não comungavam com suas próprias ideias. Ela se apresentava por meio de manuais de eclesiologia, impondo uma imagem piramidal, preocupada somente com os ministérios ordenados. Foram concepções eclesiais que prevaleceram durante muito tempo na sua história, e as consequências que trouxeram para a reflexão e a atuação do laicato ainda são percebidas no debate teológico atual. Para citar um exemplo de ordem pastoral, é só 
constatar os diferentes modelos de apostolado leigo presentes no contexto eclesial. São posturas pastorais diferentes, e até contraditórias, que se sustentam com reflexões teológicas próprias. É o caso, por exemplo, das teologias conservadoras, liberais e libertadoras, todas elas como fruto do diálogo, ou ausência dele, com a modernidade (COMBLIN, 1985; PEREIRA, 1990, p. 93-116). Cada uma delas tem a preocupação em apresentar respostas ao momento histórico e social em que está inserida. Foi nesse contexto que, gradativamente, no interior da Igreja Católica, começaram a acontecer algumas mudanças. A partir do início do século XX, a Instituição reviu sua postura, elaborando novas formas de estruturação eclesial. Foi um processo lento, mas contínuo e gradativo.

\section{A teologia apologética}

Relacionada ao modelo eclesiológico apresentado, havia uma reflexão teológica que sustentava essa visão de Igreja e de mundo: a apologética. Essa concepção se apresenta como uma reflexão conservadora diante de um determinado contexto eclesial e social, embasado no modelo piramidal da estrutura medieval. É uma postura de defesa da fé, que impossibilita o diálogo e a abertura da Igreja para refletir sobre os problemas e os desafios do mundo moderno. Os valores e as verdades que a Instituição Eclesiástica apresentava deveriam ser reconhecidos como os únicos possíveis, sem questionamentos e discussões.

Na visão apologética, a revelação já está realizada e a única depositária e responsável pela sua transmissão é a Igreja, por meio do seu corpo docente, o magistério eclesiástico. Este, dentro da apologética, não considera várias questões importantes, tais como: a liberdade, a autonomia da consciência, as descobertas científicas, entre outras. Tal visão assume como ponto de partida os diversos pressupostos não críticos e não reflexivos na abordagem teológica, propondo um conceito abstrato de revelação. A sustentação dessa postura se dava por meio de argumentos racionalistas e intelectualistas, desconhecendo a dimensão existencial, do ponto de vista antropológico, e a dimensão hermenêutica, do ponto de vista epistemológico. Tal compreensão tem uma pretensão à universalidade, 
desconhecendo, ou não querendo utilizar, a contribuição das ciências históricas e linguísticas modernas (LIBÂNIO, 1992, p. 45-49). Estes, entre outros, foram alguns pressupostos utilizados pela apologética, que distanciaram a reflexão teológica da modernidade. Tais pressupostos precisavam ser superados para que a teologia pudesse estar em diálogo com o mundo, principalmente quando se propõe elaborar uma "teologia do laicato" que responda aos novos desafios eclesiais e sociais.

Por outro lado, deve-se reconhecer que não é possível a superação de todos os limites apresentados pela Igreja nas suas diferentes etapas históricas. Porém, o que não se pode fazer é sustentar tal postura teológica, sabendo que o contexto eclesial e social em que a teologia está inserida é outro. Novos contextos exigem novos posicionamentos e valores, que devem ser assumidos com espírito de humildade e abertura.

Assim, na história do catolicismo, principalmente depois do Concílio de Trento, até a primeira metade do século XX, a Igreja assumia uma atitude teológica e doutrinal apologética. Apresentava-se dentro de uma estrutura de poder hierarquizada, que se sustentava nas leis eclesiásticas, instituídas oficialmente com o Código de Direito Canônico (CIC) de 1917, cuja vigência foi até o ano de 1983, com a promulgação do novo Código de Direito Canônico (CIC). Para se ter uma ideia, no que diz respeito à questão do laicato, no CIC de 1917 existe, ao todo, 2.414 cânones, sendo que somente dois se referem explicitamente aos leigos. O cânon 682 afirma o direito dos leigos de receber os "bens espirituais", sobretudo aqueles necessários à salvação. E o cânon 683 proíbe os leigos de usarem as "vestes clericais" (PEREIRA, 1987, p. 771-802). Era nitidamente uma eclesiologia hierarcológica, em que a Igreja Católica se identificava como Igreja do clero. Os leigos tinham uma presença passiva, entendidos simplesmente como fiéis que somente deveriam receber os bens espirituais, sempre dentro de uma rígida disciplina eclesiástica.

\section{O laicato entre os pontificados de Pio IX e Pio XII}

Na história da Igreja sempre houve uma preocupação com o laicato, que assumia características próprias em cada época. Mas, durante um 
longo período do catolicismo, se fortaleceu uma visão que considerava o leigo como um cristão que não exercia nenhuma função na Igreja. Ele apenas recebia a ação daquele que era o protagonista principal: o clero. Essa visão foi mudando, a partir dos questionamentos apresentados pela modernidade, fazendo a Igreja perceber a necessidade de envolver os leigos no apostolado. Entre os fatores que contribuíram para que a ação do leigo fosse valorizada, é possível destacar três deles: a independência da autoridade temporal, a perda dos privilégios do clero e a necessidade da atuação dos indivíduos e não mais das estruturas.

Assim, embora ainda dentro de uma Igreja entendida como "sociedade perfeita" e de uma teologia "apologética", pode-se constatar que houve uma contribuição específica no que diz respeito à questão do laicato, presente nos pontificados de seis papas (Pio IX, Leão XIII, Pio X, Bento XV, Pio XI e Pio XII) do período que antecede à realização do Concílio Vaticano II. Todos os papas mencionados estão situados no contexto da modernidade, assumindo, na maioria dos casos, uma postura de combate e de rejeição. Nesse contexto, o laicato católico é convocado a agir fazendo oposição aos elementos considerados nocivos, tanto para a Igreja Católica como para a própria sociedade. Por sua vez, tal convocação apresentou importantes elementos para a elaboração de uma experiência fundamental na Igreja, que foi a Ação Católica, instituída num primeiro momento para fazer frente aos avanços da modernidade.

Diante disso, é importante conhecer as ideias fundamentais de cada papa, priorizando os pontificados de Pio XI e Pio XII. Com eles, a Ação Católica ganhou expressividade e reconhecimento eclesial, tanto do ponto de vista jurídico como teológico e pastoral.

\section{Pio IX (1846-1878)}

Com Pio IX dava-se início às primeiras experiências mais concretas no que diz respeito à participação do leigo como colaborador do ministério sacerdotal. O papa enfatizou a ação do laicato como fundamental para a vida da Igreja. Só que sua ação deveria estar estritamente vinculada à hierarquia, como ele próprio fez questão de salientar. Sobre a temática do 
laicato, no seu pontificado, existem duas características marcantes: uma é a convocação dos leigos para combater os erros da modernidade - o laicato era chamado para exercer uma ação não de diálogo, mas de oposição ao mundo moderno; e outra, uma ação que deveria estar diretamente subordinada à hierarquia eclesiástica.

\section{Leão XIII (1878-1903)}

Os mesmos parâmetros de interpretação adotados por Pio IX foram assumidos por Leão XIII, embora seu pontificado tivesse apresentado algo novo no que diz respeito à tradicional visão da Igreja em relação ao mundo. O papa escreveu a primeira encíclica - denominada Rerum Novarum, preocupada com a questão social - e possibilitou a criação da Democracia Cristã (COMBLIN, 1996, p. 31; GUGLIELMELLI, 1947, p. 754). Sobre a problemática social, Leão XIII apresentou uma evolução significativa, não retomada por seus sucessores mais próximos. Quanto à questão do laicato, a expressão Ação Católica adquiriu caráter de cidadania, tanto no meio eclesial como no contexto social. Mas, apesar dos avanços alcançados, ainda existiam algumas questões para serem esclarecidas - uma delas dizia respeito à subordinação do leigo à autoridade eclesiástica.

\section{Pio X (1903-1914)}

$\mathrm{O}$ pontificado de Pio $\mathrm{X}$ representou um retrocesso em relação ao pontificado de Leão XIII. O papa retomou o modelo de Igreja entendida como sociedade perfeita, principalmente na sua relação com o Estado. Sobre a questão do laicato, ele apresentou várias preocupações, que estão presentes em suas primeiras encíclicas sobre a temática (Il fermo proposito e Vehementer nos). Nelas, o papa diz que os leigos devem deixar-se guiar pelos seus pastores. Suas propostas se concentravam em três campos: o primeiro era com relação à participação do leigo no apostolado da Igreja; o segundo era com a caracterização da Ação Católica, que deveria estar 
ligada a uma ação social; e o terceiro dizia respeito à subordinação do laicato à hierarquia.

\section{Bento XV (1914-1922)}

Bento XV, numa época difícil, por causa da Primeira Guerra Mundial, teve a preocupação de erradicar o modernismo da sociedade e revitalizar o poder da Igreja, entendida como sociedade perfeita. O papa insistiu na autoridade doutrinal da Igreja e escreveu sobre a questão do laicato, não apresentando nenhuma evolução a respeito. Sua preocupação era com a restauração da ordem social, a partir da perspectiva religiosa. No pontificado de Bento XV deu-se uma significativa importância ao papel dos bispos. Sobre o laicato não apresentou novidades.

\section{Pio XI (1922-1939)}

Com Pio XI, a Ação Católica foi legitimamente reconhecida como espaço de atuação do laicato. O seu pontificado foi marcado por profundos questionamentos no interior da Igreja. Encaminharam-se as reformas litúrgicas e bíblicas, dando ênfase ao movimento ecumênico. A eclesiologia passou por uma transformação, surgindo novas concepções que superavam o modelo de Igreja entendida como sociedade perfeita. No seu pontificado ocorreu, ainda, um despertar do laicato à participação e à responsabilidade na missão da Igreja, contribuindo para a promoção do próprio laicato. Explicitou-se melhor a missão do leigo na relação com o mundo, fazendo com que a Igreja começasse a penetrar ambientes que ainda não tinha acesso dentro do mundo moderno. Mas, apesar desses avanços, ainda prevalecia a ideia de que a missão a ser realizada pelo leigo era somente como um colaborador da hierarquia, numa estreita relação de dependência e subordinação.

A gênese da Ação Católica ocorreu no pontificado de Pio XI, sendo identificado como o "papa da Ação Católica" (ANTÓN, 1986b, II, p. 530; GUGLIELMELLI, 1947, p. 755). O documento que oficializa a Ação Católica 
foi a Carta Encíclica Ubi arcano. Enquanto movimento eclesial, a Ação Católica se pautava ainda nos valores hierarcológicos e na teologia apologética, que preservava os valores tradicionais da doutrina eclesiástica. Quatro causas podem ser apontadas para explicar o seu surgimento: a continuidade no governo da Igreja, a índole do pontificado de Pio XI, a espiritualidade moderna e a defesa da Igreja. Com esses elementos, a Ação Católica tornava-se um meio eficaz da ação da Igreja no mundo, sempre a partir do referencial adotado pela hierarquia católica.

Portanto, ainda se percebe uma Igreja voltada para si mesma, embora a Ação Católica apresentasse uma novidade que era o fundamento dogmático do sacerdócio dos leigos. Tal fundamento estava sustentado por uma base doutrinal e atuação pastoral, que foram se consolidando nos pontificados posteriores. Assim, era possível perceber uma viva consciência do leigo como corresponsável na missão da Igreja, sempre em colaboração com a hierarquia.

Com Pio XI, "papa da Ação Católica”, definiu-se, com mais precisão jurídica e pastoral, a atividade dos leigos, entendida como colaboração no apostolado hierárquico. Essa postura doutrinal e pastoral encerrou o pontificado de Pio XI, abrindo espaço para novas posturas teológicas, doutrinais e pastorais, que possibilitaram uma atuação laical com novas perspectivas e possibilidades.

\section{Pio XII (1939-1958)}

O pontificado de Pio XII foi marcado pelas reflexões teológicas dos períodos anteriores, pelas reformas que estavam sendo encaminhadas e pela continuidade da doutrina dos papas. Nesse contexto houve o fortalecimento da Ação Católica e, consequentemente, uma maior participação do laicato na Igreja e na sociedade.

Na primeira fase do pontificado de Pio XII (1939-1950), deram-se passos decisivos para aprofundar algumas propostas eclesiológicas e teológicas, fundamentais para a realização do Concílio Vaticano II e para os pontificados posteriores. A principal delas foi a elaboração do conceito de Igreja entendida como Corpo Místico de Cristo, presente na Carta 
Encíclica Mystici Corporis Christi (ANTÓN, 1986b, II, p. 564-675). No que diz respeito à Ação Católica, cabe ressaltar a importância da promulgação da Constituição Apostólica Bis Saeculari. A sua finalidade era afirmar que existe uma multiplicidade de formas e métodos no interior da própria Ação Católica, que não pode ser desprezada. O papa afirmava que é preciso respeitar as especificidades de cada estrutura, quando se considera a relação da Igreja com o mundo moderno.

A Constituição Apostólica Bis Saeculari confirmava, assim, o conceito jurídico da Ação Católica, apresentando as quatro notas que a constituía: a laicidade, o apostolado universal, a organização hierárquica e o mandato. Assim, foi possível a realização de novas experiências eclesiais e pastorais que aconteceram em todo o mundo católico. Um exemplo significativo foi o surgimento da JOC (Juventude Operária Católica), criada pelo padre Cardijn, que instituiu um método novo na reflexão e na ação. O método, denominado de formação na ação, se realiza a partir de três procedimentos fundamentais: ver, julgar e agir. "É o método consciente da fermentação da massa do evangelho" (HOEPERS, 1949, p. 660). Ele era utilizado para "arrebanhar" as massas para a Igreja. Posteriormente seria usado pelas pastorais específicas, principalmente a Pastoral Universitária e a Pastoral da Juventude na América Latina, numa perspectiva um pouco diferente, com características mais críticas e questionadoras, tanto da realidade eclesial como social.

Outra temática importante no pontificado de Pio XII, que contribuiu para a valorização do laicato, foi o entendimento da Igreja como Povo de Deus e Sacramento Radical (ANTÓN, 1986b, II, p. 676-831). O debate teológico que surgiu a partir desses conceitos e os pronunciamentos do magistério eclesiástico possibilitaram importantes avanços na reflexão teológica e eclesial. A Igreja assumia uma postura de maior abertura e diálogo com o mundo moderno, que foi se fortalecendo historicamente, tanto na relação com a sociedade como na própria estrutura institucional. Tais conceitos ajudaram a Instituição Eclesiástica Católica a abrir seus horizontes de interpretação, não a partir de um projeto de totalidade, entendida como sociedade perfeita, mas a partir de um novo modelo que implicaria mudanças significativas e questionadoras do modelo sustentado nos períodos medieval e moderno. 
A concepção de Igreja entendida como povo de Deus foi importante para a superação das várias visões dicotômicas - laicato e hierarquia, sagrado e profano, natural e sobrenatural, entre outras - que estavam solidificadas e fortalecidas com a ideia de totalidade eclesial. Com essa superação, ainda que incipiente, ocorreu uma recuperação da concepção bíblica, presente tanto nos livros do Antigo como do Novo Testamentos, propiciando uma reflexão sobre o laicato, entendido como protagonista da ação eclesial (FORTE, 1987, p. 28-31). A temática tornou-se significativa não só no período de Pio XII, mas na eclesiologia conciliar e pós-conciliar, apresentando um aspecto novo, já presente na tradição do povo de Israel e nas primeiras comunidades cristãs.

Um acontecimento importante no pontificado de Pio XII foi a realização dos Congressos Mundiais para o Apostolado dos Leigos. Eles não devem ser vistos como eventos isolados, mas dentro de um contexto mais amplo. Significaram um espaço alcançado pelo leigo, por meio de sua participação efetiva no interior da Igreja e na relação com o mundo. Os dois Congressos ofereceram vários elementos para a preparação do Concílio Vaticano II, realizado pouco tempo depois.

O primeiro aconteceu em Roma, no ano de 1951. Para a sua realização formou-se um comitê organizador, dirigido pela Ação Católica italiana. A preparação contou com a contribuição de diferentes associações da $A$ ção Católica. Houve uma reunião nos dias 18 e 19 de dezembro de 1950, fim do "Ano Santo" romano, que contou com a participação de mais de 100 "expertos" de 22 países e 15 organizações internacionais. Esse encontro foi para deliberar sobre o programa e o método de trabalho do Congresso. Depois aconteceu outra reunião, no mês de maio de 1951, em Paris. Com um grupo mais restrito, visava a dar os encaminhamentos finais da preparação. No Congresso participaram delegados de todos os continentes do mundo e membros das várias associações de apostolado leigo.

O Congresso se ocupou de várias deliberações importantes, refletindo também sobre a ação do leigo na Igreja e no mundo. Sua realização expressou as reflexões e debates que se faziam naquele período, principalmente no que diz respeito à questão eclesiológica. O evento apresentou cinco temas, considerados importantes para as deliberações posteriores. Dois deles merecem destaque, por se relacionarem diretamente à questão 
do laicato: a necessidade de compreender a realidade do mundo para a ação da Igreja e a formação do laicato. No que diz respeito à formação, vale ressaltar que deve sempre ser entendida como uma preocupação importante em qualquer momento da história, pois se torna urgente e necessária quando se pensa na atuação de um leigo adulto na estrutura eclesial e na relação com a sociedade.

O Congresso também possibilitou uma reflexão para compreender a atuação do laicato nas diferentes áreas da vida social, como a família, a escola, a política, entre outras. Mas a contribuição mais significativa do evento não foi a sua realização enquanto tal, e sim o fato de ter dado início a um processo de discussão mais amplo, que possibilitou a realização dos outros Congressos sucessivos, que aconteceram respectivamente em 1957 e 1967.

O Segundo Congresso Mundial para o Apostolado dos Leigos, realizado em 1957, foi preparado com uma séria reflexão teológica e pastoral. Surgiu uma imagem de Igreja que compreendia melhor as diversas funções do apostolado leigo, tanto dos homens como das mulheres. E, a partir desse referencial, a preocupação fundamental foi com a "formação de base" como um tema sempre presente nas principais reflexões e debates daquele momento importante da história do Catolicismo.

\section{A fase que antecede ao Concílio Vaticano II}

A participação do leigo no apostolado da Igreja, a partir da Ação Católica e de outros meios de atuação, mostrou a necessidade de se refletir sobre a sua missão na Igreja e na sociedade. Muitos estudos foram feitos até a década de 50, mas nada que pudesse contribuir, de maneira decisiva, para a elaboração de uma "teologia do laicato". Até aquele momento havia reflexões mais aprofundadas apenas sobre a Ação Católica, ou sobre o "sacerdócio universal dos fiéis".

A reflexão sobre o laicato surgiu, mais ou menos, ao mesmo tempo e de maneira homogênea, em vários países, principalmente na Europa. Não foi uma característica própria de um ou outro país, mas refletiu uma preocupação generalizada. "O mais curioso é que este problema não 
surgiu primeiro nas revistas profissionalmente teológicas, mas nas revistas que tratam de assuntos da vida espiritual" (SCHILLEBEECKX 1965, p. 995; GOLDIE, 1986, p. 112-113). Três pontos contribuíram para que essa reflexão acontecesse: o primeiro foi a doutrina eclesiológica vigente; o segundo foi a participação do leigo na Ação Católica e nas transformações eclesiais e sociais da época; e o terceiro foi a questão do mundo secular como problema teológico.

No que diz respeito à questão eclesiológica, como já foi mencionada anteriormente, a principal contribuição foi a doutrina teológica do Corpo Místico de Cristo e da Igreja entendida como povo de Deus. Sobre a participação do leigo foram significativas as diversas iniciativas presentes na primeira metade do século XX, como a Ação Católica e os movimentos apostólicos. Também os movimentos de renovação litúrgica e bíblica contribuíram para ampliar o espaço de participação do leigo na Igreja. E houve ainda uma importante contribuição quando se introduziu a questão da realidade secular da própria Igreja, e particularmente do leigo, como seu principal protagonista.

Assim, de uma preocupação consigo mesma, diante de um processo de secularização crescente, a Igreja abriu-se para o diálogo com o mundo moderno, entendido como espaço privilegiado de atuação do laicato. Esse diálogo influenciou a reflexão eclesiológica e o processo de elaboração da "teologia do laicato", que teve a contribuição de importantes teólogos que refletiram sobre o tema.

Uma das primeiras contribuições foi a teologia proposta por Yves Congar (1946, 1948, 1953). Para ele, o leigo era visto a partir de uma distinção dentro da própria Igreja, que se entendia como instituição e comunidade de salvação. Nessa concepção há um reconhecimento do papel sacerdotal, profético e régio do leigo na vida da Igreja, tema que foi confirmado no primeiro elemento genérico da proposta conciliar. O leigo foi definido por sua participação ativa na Igreja, entendida como povo de Deus. Ele compartilha da missão de toda a Igreja e é chamado a testemunhar sua própria fé na esfera secular, a partir de sua vocação carismática.

Um segundo autor que contribuiu para o debate sobre a questão do laicato foi Edward Schillebeeckx. Para estudar a questão do laicato, ele sugeriu uma reflexão sobre as riquezas religiosas coparticipadas pelo leigo, 
pelo sacerdote e pelo religioso. O teólogo católico belga procurou mostrar que o leigo é membro da Igreja e, consequentemente, participante ativo da sua missão, assim como os demais. A definição negativa do leigo, como aquele que não tem cargo, deve ser interpretada positivamente, porque introduz a relação distintiva dele com o mundo secular.

Um terceiro autor, importante para entender a temática do laicato, foi Hans Urs von Balthasar. Dizia ele que o leigo casado não pode se dedicar ao apostolado, porque tem muitos trabalhos mundanos. E fez uma crítica aos leigos da Ação Católica, chamando-os de "clericalizados". Portanto, para Hans Urs von Balthasar, o verdadeiro apostolado laical acontece nos Institutos Seculares, cujos membros são leigos, mas que se devotam totalmente ao apostolado.

Dentro desse debate iniciado em 1950, Yves Congar escreve outro artigo, em que define melhor o que é específico da ação do leigo. Ele (o leigo), inserido no mundo, contribui significativamente para a realização do reino de Deus, com o compromisso de ordenar a realidade secular e temporal.

Ainda em 1950 apareceram alguns textos que apresentaram uma noção negativa do leigo, tendo como referência o Código de Direito Canônico, promulgado em 1917. A noção é negativa porque diz que o leigo não tem cargo na instituição eclesial. Ele é sem jurisdição e sem poderes, que se recebem somente com a ordenação sacerdotal, segundo o magistério eclesiástico.

No ano de 1953, Gérard Philips publicava seu primeiro livro sobre o laicato. Nele, o autor afirmava que os leigos devem participar na missão primária e religiosa da Igreja. Eles devem trabalhar para a sua salvação por meio dos negócios desse mundo, exercendo duas atividades importantes, uma relacionada à Ação Católica e outra direcionada para o apostolado, como duas realidades e atividades distintas.

Karl Rahner, por sua vez, começou a escrever sobre o laicato a partir de 1954. Na sua primeira reflexão, ele colocou o elemento distintivo do leigo na relação com o mundo temporal. O leigo é um cristão e seu apostolado está relacionado com o papel que ocupa na sociedade temporal. Quando o leigo se dedica completamente ao apostolado eclesial, abandonando suas atividades leigas ordinárias, deixa de ser leigo. 
G. Baumgartner (1957) comunga com as ideias de Rahner. Para ele, o apostolado deve estar ligado à salvação do homem, sendo que para o leigo essa salvação está ligada à Ação Católica.

No ano de 1958, quem propôs uma importante reflexão sobre o laicato foi I. de la Potterie (1958, p. 840-853; 1967, p. 15-32), apresentando um estudo semântico da palavra leigo. Desenvolveu a reflexão a partir dos termos laicus e laikos, como eram utilizados na Igreja primitiva. A palavra laos no mundo greco-romano se referia ao povo em oposição aos líderes ou aos governantes. Era uma noção funcional, no sentido de que a pessoa não pertencia à classe intelectual, oficial ou dirigente da sociedade. $\mathrm{Na}$ Bíblia, segundo I. de la Potterie, se usa a palavra laos para falar do povo de Deus, com a matriz greco-romana.

Considerando esse rápido panorama histórico, de fundamentação teológica e doutrinal, surgem algumas preocupações importantes. Uma delas é com a própria definição teológica do termo leigo. A evolução da ação e consequente reflexão sobre o laicato contribuiu para uma definição eclesiológica. O leigo, como membro da Igreja, ficou incorporado ao mundo secular. Há, assim, uma maior relação do catolicismo com o mundo, por meio da atuação do leigo. Essa interpretação contribuiu para as reflexões teológicas sobre o leigo no Concílio Vaticano II que, apesar de muitas iniciativas positivas a respeito do laicato, não conseguiu apresentar uma solução definitiva e plausível para o problema. Apesar dessa limitação, já na fase pós-conciliar aconteceram muitos eventos e estudos, que procuravam aprofundar a temática do laicato na sua relação com a Igreja e com o mundo, principalmente nos pontificados de Paulo VI e João Paulo II. Também ocorreram muitas iniciativas realizadas pelas Conferências Episcopais em diversos países do mundo, cujo objetivo era aplicar as conclusões conciliares à realidade local de cada Igreja particular.

\section{Algumas conclusões e questionamentos}

Na primeira metade do século XX, a Igreja Católica passou por experiências que marcaram sua realidade interna e consequente relação com o mundo. O desafio de se relacionar com a sociedade moderna fez 
com que ela fosse envolvida por essa mesma realidade. Tal situação possibilitou um diálogo com o novo contexto social, que apresentava características próprias, diversas de outros tempos. A ação do Espírito foi quem a conduziu por um caminho pouco desejado por alguns. Isso porque muitas mudanças propostas pelo período pré-conciliar e conciliar não foram assumidas por vários setores da Igreja. Essa oposição foi percebida, por exemplo, quando morreu João XXIII e se pensou na escolha do novo papa. A preocupação naquele momento era pela continuidade ou não dos encaminhamentos do Concílio. Um exemplo de não aceitação das propostas conciliares aconteceu com o bispo francês Marcel Lefèbvvre (LIBÂNIO, 1984, p. 119-130). Foi o momento em que a Igreja retomou vários conceitos que tinham sido esquecidos na sua milenar caminhada histórica e institucional e, ao mesmo tempo, passou por vários questionamentos, exigindo um posicionamento coerente diante dessa realidade.

Nesse contexto eclesial e social, pleno de desafios e ao mesmo tempo de esperanças, terminava o pontificado de Pio XII, com sua morte no dia 9 de outubro de 1958. Surgia a necessidade de escolher um novo pontífice, que encaminhasse essa realidade eclesial em transformação. Assim, assumiu o trono pontifício o cardeal Angelo Giuseppe Roncalli, no dia 28 de outubro de 1958, com o onomástico de João XXIII (FISCHER-WOLLPERT, 1991, p. 164). Ele, a menos de 90 dias da sua escolha, fez a convocação do Concílio Vaticano II, cuja promulgação e posterior realização se tornaram um marco importante na vida da Igreja, e pode ser visto como uma nova etapa na relação da Igreja com o mundo moderno.

Mais do que preocupar-se com os problemas externos à realidade eclesial, o Concílio se tornou "um Concílio de Igreja sobre a Igreja", embora não tenha deixado de se preocupar com a realidade social. Mas a Igreja ainda tinha dificuldade em aceitar o mundo moderno, inclusive com a preocupação de resolver certas questões internas que mereceriam maior atenção, segundo o próprio magistério eclesiástico. O fato é que a Igreja precisava mudar internamente, enquanto concepção de si mesma e, assim, se posicionar dialogicamente na sua relação com o mundo.

Sobre a questão do laicato, nesse período que antecede à realização do Concílio Vaticano II, algumas questões podem ser levantadas. Até que ponto a Igreja possibilitou a participação ativa do leigo? Em que sentido 
deve-se compreender essa participação? Pode-se falar de uma "teologia do laicato" que não seja entendida apenas como subordinação a uma teologia clerical? O leigo é considerado adulto na relação com a hierarquia? Sua ação não está subordinada a essa mesma hierarquia, sem que possa assumir posições próprias e autônomas? Estas são questões que devem estar presentes quando se propõe estudar o Concílio Vaticano II e a etapa pós-conciliar. Mas essa meta não se insere na perspectiva deste artigo, ficando as referidas questões para serem respondidas em outro momento, que será preparado especificamente para essa finalidade.

\section{Referências}

ANGELOZZI, G. Le confraternite laicale: un'esperienza cristiana tra medioevo ed età moderna. Brescia: Queriniana, 1978.

ANTÓN, A. El misterio de la Iglesia. Evolución histórica de las ideas eclesiologicas. v. 1. Madrid: BAC, 1986a.

ANTÓN, A. El misterio de la Iglesia. Evolución histórica de las ideas eclesiologicas. v. 2. Madrid: BAC, 1986b.

BAUMgartner, G. Formes diverses de l'apostolat des laïcs. Christus, v. 13, p. 9-33, 1957.

COMBLIN, J. Teologia da libertação, Teologia neo-conservadora e Teologia liberal. Petrópolis: Vozes, 1985.

COMBLIN, J. Cristãos rumo ao século XXI. Nova caminhada de libertação. São Paulo: Paulus, 1996.

CONGAR, Y. Sacerdote et laïcat dans l'Eglise. La Vie Intellectuelle, v. 14, p. 6-39, 1946.

CONGAR, Y. Pour une théologie du laïcat. Études, v. 81, p. 42-54, 1948.

CONGAR, Y. Jalons pour une théologie du laïcat. Paris: Cerf, 1953. 
COVOLO, E. et al. (Org.). Laici e Laicità. Nei primi secoli della Chiesa. Milano: Paoline, 1995.

DE LA POTTERIE, I. L'origine et le sens primitif du mot "laïc". Nouvelle Revue Théologique, n. 80, p. 840-853, 1958.

DE LA POTTERIE, I. La palabra "laico". Origen y sentido primitivo. In: DE LA POTTERIE, I.; LYONNET, S. La vida según el espíritu. Salamanca: Sígueme, 1967. p. 32-45.

DUPUIS, J. Gesù Cristo incontro alle religioni. Assisi: Cittadella, 1991.

fischer-WOllpert, R. Léxico dos Papas - de Pedro a João Paulo II. Petrópolis: Vozes, 1991.

FORTE, B. Laicado y Laicidad. Ensayos eclesiológicos. Salamanca: Sígueme, 1987.

GOLDIE, R. Laici, laicato, laicità. Bilancio di trent'anni di bibliografia. Roma: AVE, 1986.

GUGLIELMELLI, D. Pio XI e a Ação Católica. REB, v. 7, p. 754-792, 1947.

HOEPERS, M. Esclarecimentos Jurídico-Práticos sobre a Ação Católica na "Bis Saeculari". REB, v. 9, p. 636-670, 1949.

LIBÂNIO, J. B. A volta à grande disciplina: reflexão teológico-pastoral sobre a atual conjuntura da Igreja. São Paulo: Loyola, 1984.

LIBÂNIO, J. B. Teologia da revelação a partir da modernidade. São Paulo: Loyola, 1992.

PEREIRA, A. S. Participação dos leigos nas decisões da Igreja à luz do Código de Direito Canônico (III). REB, v. 47, p. 771-802, 1987.

PEREIRA, A. S. Participação dos leigos nas decisões da Igreja à luz do Vaticano II (IV). REB, v. 50, p. 93-116, 1990.

PHILIPS, G. Le rôle du laïcat dans l'Eglise. Paris: Castermann, 1953.

RAHNER, K. L'apostolat des laïcs. Nouvelle Revue Theologique, v. 1, p. 3-32, 1956. 
SCHILLEBEECKX, E. A definição tipológica do leigo cristão conforme o Vaticano II. In: BARAÚNA, G. A Igreja do Vaticano II. Petrópolis: Vozes, 1965. p. 981-1000.

SEMERARO, M. La figura del laico nella storia. Credere Oggi, v. 3, n. 81, p. 21-31, 1994.

\section{Documentos do magistério}

PIO IX. Syllabus complectens praecipuos nostrae aetatis errores qui notantur in encyclicis aliisque apostolicis litteris sanctissimi domini nostri Pii Papae IX (0812-1864), ASS 3 (1867-68), p. 168-176.

PIOX. Carta Encíclica Il fermo proposito ASS 37 (1904), p. 747-767; in Insegnamenti Pontifici - 4, Il Laicato. Sue posizioni e suoi ordinamenti, Roma, 1958, p. 211-231. 11 jun. 1905.

PIO X. Epistola Encíclica Vehementer nos (11-02-1906), ASS 39 (1906), p. 3-16.

LEÃO XIII. Carta Encíclica Rerum Novarum (15-05-1891), ASS 23 (1890-91), p. 641-670.

BENTO XV. Codex Iuris Canonici, AAS 9 (1917), p. 11-456

BENTO XV. Carta Encíclica Spiritus Paraclitus (15-09-1920), AAS 12 (1920), p. 385-422.

BENTO XV. Epístola Cum semper (10-02-1921), AAS 13 (1921), p. 127-130.

BENTO XV. Epístola Libenter quidem (15-10-1921), AAS 14 (1922), p. 7-10.

PIO XI. Carta Encíclica Ubi arcano (23-12-1922), AAS 14 (1922), p. 673-700.

PIO XII. Carta Encíclica Mystici Corporis Christi (29-06-1943), AAS 35 (1943), p. $193-248$.

PIO XII. Constituição Apostólica Bis saeculari (27-09-1948), AAS 40 (1948), p. 393-402. 
CONSELHO DE LEIGOS. Segundo Congresso Mundial para el Apostolado de los laicos; volume I: Los laicos en la Iglesia; volume II: Frente al mundo de hoy; volume III: Formar apóstoles, COPECIAL, Roma 1958 («Actes du Troisième Congrès Internationaux pour l'Apostolat des Laïcs» [3 volumes], Roma, 1967.

Recebido: 20/12/2010

Received: 12/20/2010

Aprovado: 10/02/2011

Approved: 02/10/2011 